\title{
Legal Perspective in the Study of the Fulfillment of Educational Rights for Unafficient Children in the Pandemic Period
}

\author{
Gusjoy Setiawan ${ }^{1}$, Suparno ${ }^{2}$ \\ Universitas Borobudur Jakarta ${ }^{1,2}$ \\ \{gusunbor@gmail.com¹, suparno@borobudur.ac.id²
}

\begin{abstract}
Children are a valuable asset of a nation, so the quality and future projections of children must be considered because they will affect the future life of the nation and state. Considering the urgency of competent human resources, namely those who have good knowledge, skills, and attitude as an effort to advance the nation, the state must pay serious attention to the protection and fulfillment of the right to education for children. The issue of equal distribution of education, which is still being pursued so that it can be realized, received a test when the Covid-19 pandemic was present. The application of online learning which is considered the best choice is difficult for students from underprivileged families. It is not uncommon for choices that are difficult to make, children lose their education and even choose to work to help their parents make a living. The results showed that the fulfillment of the right to education for underprivileged children was legally guaranteed. As a form of legal guarantee for the fulfillment of the right to education for underprivileged children, the government needs to take additional steps to help underprivileged children by collecting data for underprivileged students, extending the learning quota package assistance during the online learning period, opening special assistance receiving posts for students. or underprivileged students, as well as forming a supervisory team so that beneficiaries can directly receive and use them for online learning. The results showed that the fulfillment of the right to education for underprivileged children was legally guaranteed. As a form of legal guarantee for the fulfillment of the right to education for underprivileged children, the government needs to take additional steps to help underprivileged children by collecting data for underprivileged students, extending the learning quota package assistance during the online learning period, opening special assistance receiving posts for students. or underprivileged students, as well as forming a supervisory team so that beneficiaries can directly receive and use them for online learning. The results showed that the fulfillment of the right to education for underprivileged children was legally guaranteed. As a form of legal guarantee for the fulfillment of the right to education for underprivileged children, the government needs to take additional steps to help underprivileged children by collecting data for underprivileged students, extending the learning quota package assistance during the online learning period, opening special assistance receiving posts for students. or underprivileged students, as well as
\end{abstract}


forming a supervisory team so that beneficiaries can directly receive and use them for online learning.

Keywords: Law; Education Rights; Underprivileged Children; Pandemic

\section{Introduction}

The Covid-19 pandemic, which is currently still hitting various countries around the world, has not been completely handled. Many changes and adaptations have been made for the creation of a normal life like before the emergence of Covid-19. Various efforts have been made, both by taking care of personal health, namely using masks and washing hands regularly, limiting the crowd, and minimizing the mobility of the public. The government has disseminated various policies including policies for the industrial sector, transportation, education, and religion. In this case, the changes that are being felt by the younger generation who are the largest population in Indonesia today are related to the online learning policy.

For families living in the poverty line, it becomes a heavy burden to provide online learning tools for their children. They must try hard to be able to fulfill their daily needs, but also consider meeting their children's educational needs. Astrid Gonzaga Dionisio, Child Protection Specialist UNICEF Indonesia, assumed that the distance learning system from home cannot be done optimally by all children. This condition can put children living in vulnerable families at risk.[1] It is usual for these families to give up and leave their children out of school for a while. If this is allowed, there will be many more young people who will lose their future. This research here presents the facts of the difficulty of fulfilling education for underprivileged children during this pandemic and how legal studies view the fulfillment of the right to an education that should be received by every child. This research is expected to provide consideration for related parties who are responsible for children's education so that they can provide solutions, assistance, and facilities for underprivileged children in fighting for their education.

\section{Method}

To get a picture that is closely related to the real phenomenon in society, the researchers used a qualitative approach with descriptive-analytic methods. The analytical descriptive method is a method that functions to describe or give an overview of the object under study through the data collection as it is without analyzing and making general conclusions.[2] Analytical descriptive research takes problems or focuses on problems as they are when the research is carried out, the results of existing research are then processed and analyzed to conclude. Data collection in this study is through observation and literature review in the form of information about online learning difficulties for underprivileged children and how the legal side sees this. This research is aimed at getting an idea of how the legal point of view guarantees the fulfillment of children's education and the solutions offered considering that underprivileged children have not received this fulfillment of education, especially during this pandemic.

\section{Result}




\subsection{The phenomenon of the application of online learning in Indonesia}

Distance Learning using Online which is currently practiced for the world of Education is considered the best choice for efforts to increase the knowledge and skills of students during the Covid-19 pandemic.[3] For Indonesian students, losing time to study at school is a disadvantage. It is because they noticed that school is a place to socialize, communicate, a place to play, and form a peer community for students. It's not only creates learning difficulties but also affects the mental health of students. The students' psychological state experiences a situation where they are always aware of the environment in which they live their daily lives (worried about contracting Covid-19). This condition causes mental health problems, one of which is psychosomatic disorders, anxiety, panic, and fear. Suggestions that are built into the mind greatly affect the physical and psychological conditions in this situation.[4]

The Ministry of Education, under the leadership of Minister Nadiem Makarim, echoes the spirit of increasing productivity for students to raise job opportunities when they graduate from school. However, with the presence of the Covid-19 pandemic, education in Indonesia needs to follow a flow that can help school conditions in an emergency. Schools need to force themselves to use Online media. However, the use of technology has its problems, many obstacles or problems hinder the effectiveness of learning with online methods.[5]The biggest obstacle is the limited mastery of information technology by teachers and students. This is because teachers in Indonesia come from all ages and walks of life. Information technology constraints limit their use of online media. Likewise, students who are currently the millennial generation allow faster learning using various applications and technology, but economic limitations often become an obstacle for students to follow Online learning policies.

Considering that there are numerous Indonesians who are below the economic line of poverty, the implementation of online learning needs attention, especially for underprivileged students. The welfare of the students' families limits those who are still very limited in their lives having difficulties in providing information technology facilities and infrastructure that are indispensable with a learning model during the Covid-19 pandemic disaster. Besides, concerning Internet access, conditions in Indonesia have not allowed a comprehensive online policy because a truly strong and adequate internet network is still not evenly distributed in all corners of the country in Indonesia. Oktoriyadi is a teacher who teaches at the state elementary school in Kapuas Hulu Regency, West Kalimantan, who said that it had been three months since his students had not experienced the education they should have. Instead of studying at home, the students now only help their parents in the fields because there is no internet service in the village.[6] He argues that the online learning policy is not suitable for his region because of internet network difficulty. Besides, the economic conditions of the families of the people are very dependent on nature so that it is impossible to provide online learning infrastructure for children. If this continues, the level of education in the region will be even lower. Of course, this will affect not only the future of the child personally but also as a whole on the efforts to educate the nation's children, which is the ideal of the Indonesian nation.

\subsection{The Effect of the Family Economy on the Sustainability of Children's Education}

Learning through the online system may not be a problem for children from financially wealthy families. But it is different for children from poor families. Studying online requires a large internet quota, which makes it hard for those in an underprivileged economy. Amhal Kaedahmi, Ministry of Religion Madrasah Superintendent in Semarang City, revealed his 
findings that learning online from home was deemed ineffective for children from underprivileged families.[7] The same thing was conveyed by the head of MI Infarul Ghoy, Ida Khoirun Nisa, and the head of MI Kalimatullah, Masqobah. According to them, spending on the internet quota is considered very heavy, so online learning has not been maximal. Meanwhile, the head of RA Al Iman, Pujiarti, and the head of RA Nurus Syuja ', Eny Purwati said that it was not only the teachers but also the students' parents who were part of the underprivileged class. This system is difficult to be effectively operated for children from underprivileged families, because of the limitations of their parents in supervising and providing devices and internet networks.

Thus, can be understood that the limitations of existing facilities cannot counterbalance the learning process that usually occurs in class with direct meetings.[8] Another problem that is of concern to the Indonesian Child Protection Commission (KPAI) is the emergence of a crisis in the education of children in Indonesia. The gap among students occurs between groups of capable and poor students. With the shift from conventional learning systems in the classroom to a distance learning system that prioritizes internet network connections and means of connecting them, access to education is slightly limited. For groups of capable students, there are no obstacles in using distance learning facilities. They can provide the necessary tools and follow the learning. Meanwhile, groups of underprivileged students who experience limitations in the provision of facilities will experience enormous obstacles in accessing the education they are entitled to.

\subsection{Legal Studies on the Fulfillment of the Right to Education for Children}

The Conference on the Rights of the Child (CRC) has become part of national law, after being ratified by Presidential Decree No. 36 of 1990. Post-reform, the Government has ratified several important international human rights law instruments and many have initiated efforts to normalize human rights by promulgating several laws and regulations. The fulfillment of children's rights must pay attention to the social environment, including social and cultural values, which encompass children's lives. According to Urie Bronfenbrenner, children are part of the broader community so that there is a greater power in a society that is an important part of the ecology of child development.[9] The effectiveness of laws that regulate child protection can be seen when the products of these laws are enforced, especially to respond to cases experienced by children, whether in the family, community, or community.

Understanding the importance of the child's right to education must be returned to the basic principles of fulfilling children's rights, namely non-discrimination, life, growth and development, the best interests of the child, and participation.[10] This is in line with Article 26 paragraph 1 of the Universal Declaration of Human Rights, namely that everyone has the right to education. Education must be free, at least at the basic level so that it proves that the government defends society in meeting the needs of education for all circles. In article 26 paragraph 2 Education should be directed at the full development of the human personality and to strengthen respect for human rights and basic freedoms.

As a country that is serious about upholding and respecting human rights, the Indonesian state has issued Law No.39 of 1999 concerning Human Rights. The tenth part of the law contains the rights of children, especially the rights of children regarding education contained in article 60 paragraph 1: "Every child has the right to education and teaching in the framework of personal development according to their interests, talents, and level of intelligence." Getting an education, health and a decent life are the rights of all Indonesian citizens, especially school-age children as stated in the Child Protection Law No.23 of 2002 
concerning Children Protection, which also regulates children's rights, including the right to life, the right to name, the right to education, basic health, worship according to their religion, expression, thinking, playing, recreation, rest, social and social security. Indonesia as a state based on law is the first slogan of the state government system according to the 1945 Constitution which means that it adheres to Rechstaat and not machtaat, a rule of law and respect for human rights.[11]

The views and thoughts on the fulfillment and protection of children's rights demand that adults (biological parents, government, society) are fully responsible for every child born by anyone and anywhere in the world.[12] This effort needs to be done together with government assistance as an education facilitator and protector of children's rights. By law, every child has equal rights and opportunities in education. Therefore, the pandemic problems faced by various groups and social status must be shared learning to help each other, not to be suspicious of each other. Providing assistance from the government and people who are better off is needed to help facilitate underprivileged students. The government can work together to provide tools and infrastructure for underprivileged students with the following steps:

a. Carry out data collection for underprivileged students. In this case, the data collection is carried out in detail so that the assistance can be right on target.

b. The study quota package that has been distributed by the government so far can be extended again as long as the online learning period continues.

c. Opening special assistance admissions posts for underprivileged students or students. Those who want to participate in helping underprivileged students can contact these posts. Assistance can be in the form of a quota package or a digital learning tool fit for use

d. In its distribution, a supervisory team is needed so that beneficiaries can directly receive and use it for online learning.

The things mentioned above certainly do not necessarily provide a complete solution to this problem. Considering that the problem of poverty is a problem in various parts of the country, it is necessary to handle it in stages according to existing cases. It is hoped that these steps can make it easier for underprivileged students to be able to fight for their education in the current online learning period.

\section{Conclusion}

Online learning during the Covid-19 pandemic gave a new face to the world of education. In its implementation, there is a dilemma for students who are less well off financially. They need help so that they can follow online learning well. The absence of facilities in the form of gadgets or laptops, as well as internet coupons, is a difficult struggle for them. The poor family economy often makes difficult choices for children to fight for their education. They will choose to be able to make a living with the available money instead of buying internet quotas because that is their best choice. As a country that guarantees children's education legally, the government is obliged to help students who experience these difficulties. Strong Education Guarantee, will help developed countries because they can supply young generations who are capable, clever, and skilled. Therefore, a synergy is needed from the Government and the people who are financially able to help them. 


\section{Reference}

[1] Deonisia Arlinta, "Online Learning Is Less Effective In Poor Families," Kompas.id, Apr. 03, 2020.

[2] Sugiyono, Quantitative Research Methods, Qualitative and $R \& D$. Bandung: PT Alfabet, 2016.

[3] Rizqon Halal Syah Aji, "The impact of Covid-19 on education in Indonesia: Schools, Skills, and the Learning Process.," J. Sos. Syar-i culture., vol. 7, no. 5, 2020.

[4] Nurkholis, "The impact of the novel-corona virus disease (covid-19) pandemic on psychology and education as well as government policies.," J. PGSD, vol. 6, no. 1, pp. 39-49, 2020.

[5] Y. Pujilestari, "The positive impact of online learning in the Indonesian education system after the Covid-19 pandemic.," Is Bul. Huk. and Justice, vol. 4, no. 1, pp. 49$56,2020$.

[6] Callistasia Wijaya, "Schools in the midst of the Covid-19 pandemic: Students are 'left behind' academically, parents: 'I choose safe children'.," BBC News Indonesia, Jun. 02, 2020.

[7] "Amhal Kaefahmi: Obstacles to Learning Through Online for Poor Families.," Ministry of Religion of Central Java, Semarang, Apr. 06, 2020.

[8] A. Purwanto et al., "An Exploratory Study of the Impact of the COVID-19 Pandemic on Online Learning Process in Elementary Schools," EduPsyCouns J. Educ. Psychol. Couns., Vol. 2, no. 1, pp. 1-12, 2020, [Online]. Available: https://ummaspul.ejournal.id/Edupsycouns/article/view/397.

[9] Adzkar Ahsinin., "Critical Study of the Implementation of the Fulfillment of Children's Rights in Indonesia.," Pp. 1-18, [Online]. Available: https://kajiangender.sksg.ui.ac.id/wp-content/uploads/2016/04/Kajian-Kritis-terhadapImplementasi-Pemenuhan-Hak-Anak.pdf.

[10] HAR Tilaar, Power and Education An Overview of the Perspective of Cultural Studies. Magelang: Indonesia Tera, 2003.

[11] Tatik Mei Widar, "Fulfilling the Right to Education of Correctional Students in Child Prisons.," DIH J. Legal Studies., vol. 8, no. 15, pp. 28 - 47, 2012, [Online]. Available: https://media.neliti.com/media/publications/240057-pemenuhan-hak-pend Pendidikananak-didik-pema-a6f798be.pdf.

[12] Hadi Supeno, Criminalization of Children Offers Radical Ideas of Juvenile Justice Without Criminalization. Jakarta: PT Gramedia Pusaka Utama, 2010. 